\title{
Imaginative Geographies of Green: Difference, Postcoloniality, and Affect in environmental narratives in contemporary Turkey
}

\section{LEILA M HARRIS}

Corresponding Author: ilharris@ires.ubc.ca

Final version: Harris, L. M. (2014). Imaginative geographies of green: difference, postcoloniality, and affect in environmental narratives in contemporary Turkey. Annals of the Association of American Geographers, 104(4), 801-815.

Citations of this work should use the final version as noted above 


\section{ABSTRACT}

Analyzing everyday environmental imaginaries from contemporary Turkey through the lenses of postcolonial, emotional-affective, and nature-society geographies, this article offers insights into shifting nature-society relations and possibilities. Based on a series of interviews and focus groups conducted in four sites (Istanbul, Ankara, Diyarbakir, and Sanliurfa), the concept of imaginative geographies of green is offered to highlight social and spatial difference as central to the articulation of green visions and movements. The research foregrounds several social and spatial gradients specific to the Turkish context, including East-West divides both within and beyond Turkey (i.e., KurdishTurkish and Eastern-Western Turkey, as well as notions of Turkishness and Europeanness ). The work also suggests that environmental imaginaries have deeply emotional, ambivalent, and power-laden associations. Apart from the implications of the work for enriched understandings of emergent environmental possibilities in this context, the conclusion also touches on ramifications for EU accession debates as well as new directions for work on environmental citizenship and movements in the global South.

Key words: Environmental politics, Turkey, EU, environmental imaginary, postcolonialism, affect, Global South 


\section{INTRODUCTION}

In his 2006 Nobel Prize acceptance speech, noted Turkish novelist Orhan Pamuk recalls a childhood memory of looking at his father's vast library, and his realization that it was by European thinkers. Writers from Turkey were relegated to a minor section of the collection. To describe what he felt at this moment, and what he continues to feel as a writer from Turkey, Pamuk invokes the literary concept of hüzün-the melancholy that is produced when one is confronted by peripherality and loss. This is the feeling, he explains, that is generated when Europe is presented as a "'ready-made civilization for everyone"' and when people are expected to blindly emulate Europe's example (Pamuk 2006a, 2006b, also discussed in Atasoy 2009).

Interrogating the implications of providing the West as a model with respect to green movements and imaginaries, this piece considers notions of social and spatial difference, including "European" and East-West as they are narrated and reflected in everyday environmental imaginaries from contemporary Turkey. Offering a postcolonial and emotional-affective reading of these narratives, I build on a number of recent humanities contributions including Postcolonial Environmentalism and Postcolonial Green that similarly interrogate the power-laden and affective aspects of contemporary green visions, movements, and literatures (Nixon, 2005, 2011l Huggan and Tiffan 2007). I also further the insights of foundational geographic works that have emphasized postcolonial histories and geographies in nature-society dynamics (Willems-Braun, 1997; Wainwright 2005; Robbins 2006). Willems-Braun, for instance, offers a postcolonial critique of state building and governmentality in Canada to unpack the ways in which European domination infuses geological sciences and contemporary ecological debates. Wainwright similarly challenges nature-society geographers to critically interrogate, rather than to endorse and affirm, colonial logics that align with notions of territoriality and space. A broader set of works have also contested the Orientalist imposition of environmental politics and practices on peoples and places of the global South-for instance, countering characterizations of third-world women as an environmental "problem"(Sawyer and Agrawal 2000), confronting the exclusion of local livelihoods that proceed with biodiversity conservation efforts (e.g. Neumann 1998), or critically interrogating Northern consumptive and philosophical practices (Guha 1989, 1997).

Taking up these themes, the analysis of this article draws on the concept of environmental imaginaries (Davis and Burke 2011) and several postcolonial analytics, including imaginative geographies (Said 1978), mimicry and ambivalence (Bhabha 1994). The concept of imaginative geographies of green references these resources, and serves to emphasize social and spatial difference as central to environmental 
imaginaries and expressions. Considering several such social and spatial gradients of particular importance to the case study site (e.g. East-West, Turkish-Kurdish, or TurkeyEurope), the analysis also necessarily incorporates emotion, affect, and ambivalence. In terms of what this offers to postcolonial nature-society studies, the contribution extends focus beyond the metropole and outside of common centers of control and power (e.g. state, scientific, or mainstream environmental discourses and practices). It also is unique among these discussions for thinking through the connections to emotional and affective geographies. Regarding debates on environmental citizenship and emergent environmental movements, the contribution also makes a strong case for the importance of postcolonial theory to issues of environmental citizenship and politics in the global South. Following a brief discussion of the theoretical commitments guiding this research, I turn to an overview of current work on environmental citizenship and politics with a focus on Turkey and the global South. I then analyze key themes in lay narratives mobilized by respondents-paying particular attention to East-West gradients both within and beyond Turkey. I argue that understanding these complex and ambivalent mappings is important not only for an appreciation of green politics and possibilities in Turkey (and the global 'South) but also given relevance for European Union (EU) accession debates as well as for efforts to decolonize nature-society geographies more generally.

\section{APPROACHING GREEN: POLITICS, MOVEMENTS, AND SUBJECTIVITIES IN THE GLOBAL SOUTH}

Imaginative geographies of green, environmental imaginaries, and enriching postcolonial nature-society debates

In a recent insightful work, The Key of Green, cultural historian Bruce Smith (2008) provides a treatment of the color green from varied cultural, historical, and philosophical perspectives. Smith suggests that colors are not attributes of things but rather the way that we perceive those things (for instance, he notes that certain cultures may not differentiate greens from blues). He therefore argues that green be understood as a relational concept that can only be approached through consideration of perception, the senses, and cultural-contextual differences. Applied to "green" politics and movements, these insights set up a framework to evaluate environmentalisms as relational, dependent on sensory evaluations, and historically and culturally contingent; a perspective that resonates with the varied visions of nature proposed in scholarship on environmental imaginaries (see Davis and Burke 2011 for an examination of the concept in Middle Eastern contexts).

The analysis here builds on these foundations, and also draws on several postcolonial analytics. Said's (1978) concept of imaginative geographies examines the 
representation of peoples and places-with Orientalist framings of some people and places as backwards or exotic in a way that at once serves to characterize the "metropole" as "normal," forward-looking, or "civilized." As he argues, these representations are not mere literary tropes but serve to justify colonialism (see Gregory 2004 for an example of linking imaginative geographies of the Middle East to contemporary warfare). Uniting these concepts, imaginative geographies of green foregrounds how "differences'" are mapped against and read through green subjectivities, visions, and movements-including associations with self-Other, or EastWest.

Two additional concepts-mimicry and ambivalence (Bhaha 1994) -complement and further this postcolonial reading of green politics and possibilities. Mimicry (Bhaha 1994) refers to the mandated -but also longed for-replication of the colonizers' practices and institutions. The necessary failure of such replication (due to racialized or other difference, as captured by the turn of phrase "not white not quite") inevitably leads to a sense of loss. Ambivalence similarly opens up the realm of the affectivehighlighting the possibility that there may be mixed or even contradictory associations with colonial relations and processes (see Harris 2008 for an analysis of these concepts in relation to Turkish developmentalism). The analysis that follows engages these ideas to firmly situate everyday notions of 'green' within the realm of postcolonial theorization and critique (see also Guha 1989; Agyeman and Evans 2006; Rutherford 2007; Latta 2007). In so doing, the contribution helps to make some headway towards the imperative to "unmap" or "rewrite" our understandings of other "worlds" (cf. Razack 2002; Sparke 2007; Spivak 2008) in ways that refuse problematic pre-given colonial categories (cf. Wainwright 2005) instead seeking to rethink histories, politics, and ecologies by building on and reaffirming anti-colonial orientations (cf. Chakrabarty 2000; Lawhon et al, 2012). The following sub-section contextualizes the imperative to think and write green visions and movements differently by providing some notes on the other treatments of Turkish (and Southern) environmental visions and movements available to date.

\section{Southern Environmental Politics and Turkish Environmentalisms}

Broadly, evaluations of green visions and movements in the global South have tended to rely on several methods and theoretical perspectives. A significant subset of this work relies cross-national surveys to correlate environmental values with levels of democracy or economic development (e.g., Lafferty and Meadowcroft 1996; Gleditsch and Svedrup 2002; Gerhards and Lengfeld 2008). ${ }^{\text {ii }}$ A smaller subset of scholarship from anthropology and other qualitative fields focuses on the contextual and socio-cultural dimensions of Southern green movements -including their embeddedness in broader historical and geographical relations, politics, and constellations of meaning (see Brosius 1999; Paley 2002; Tsing 2005) and their connections to local histories, 
institutions, social structures, or class differences (for several key examples, see Mawdesley 2004; Alatout, 2006; Ignatow 2008a; for a general discussion of Southern environmentalism, see Gardner 1995; Haynes 2009). Recent work on green citizenship considers pathways through which to foster green subjectivities (i.e., "making people more environmental," e.g. Dobson and Bell 2006) including the role of education in fostering green values (see Tuncer et al. 2005, 2009; Ozden 2008; Ignatow 2005, $2008 \mathrm{~b}$ for Turkish and cross-national analyses) and the possibilities that devolved resource governance institutions condition new environmental subjects (Agrawal 2005; Haggerty 2007). Several contributions that highlight power dynamics, political economic context, and inequality and social difference in relation to emergent green subjectivities (Guha 1989; Agyeman and Evans 2006; Rutherford 2007; Latta 2007; Author 2011) also serve to lay the groundwork for the analysis here.

Specific to Turkey, the literature on environmental politics, movements, and subjectivities ey remains relatively thin.iii Nonetheless, the volume Turkish Environmentalism (Adaman and Arsel 2005) provides several themes that are picked up here, including the significance of EU accession in altering Turkey's non-governmental landscape as well as the role of history and cultural traditions in conditioning emergent environmentalisms. Other research has indicated strong support for conservation among Turkish youth, gender differences in environmental attitudes, and a continuing need to assess regional influences on environmental attitudes given political-economic disparities across the country (Tuncer et al. 2005). A recent companion piece has also evaluated scalar dimensions of lay environmental narratives in Turkey, arguing that a focus on the 'local' has the effect of masking other broader scale or less visible environmental challenges (e.g. climate change, Author, 2011).

Echoing a theme common to many discussions of Southern environmentalism generally, green politics in Turkey are frequently cast as lagging, embryonic, and in need of development; a piece by sociologists Gerhards and Lengfeld (2008) is emblematic in this regard. Comparing responses to a values survey across EU and accession countries, ${ }^{\text {iv }}$ the researchers conclude that the vast majority of Europeans are supportive of the EU's environmental policy agenda-with two exceptions: Turkey and Hungary, both of which are characterized as lagging with respect to environmental values. The belief that Turkey lags behind neighboring Europe is a narrative with deep lineage in Ottoman and Kemalist temporalities and discourses-a sensibility that also serves to undergird contemporary EU investments in Turkish civil society development. v

The analysis that follows contributes a needed qualitative dimension to these discussions with a dozen focus groups and a similar number of interviews carried out in 2005 and 2007 in four cities (Turkey's largest cities of Istanbul and Ankara as well as two smaller, but growing, urban areas in the Southeastern Anatolia region: Diybabakir 
and Sanliurfa). Interviews were conducted with many of Turkey's major environmental NGOs (e.g. TEMA, Greenpeace) and with a smaller set of environmentally engaged groups in the southeastern sites (where few environmental NGOs are present). Focus groups were conducted in three sites (Sanliurfa, Diyarbakir, and Istanbul) and involved mostly urban residents (one group in Urfa involved rural residents). With the exception of one focus group in Diyarbakir that involved individuals active in environmental efforts, all of the remaining focus groups were comprised of citizens who did not necessarily identify with, or claim interest in, environmental issues. Given the focus of the research on lay environmentalisms and everyday meanings (rather than media representations or political discourses), focus group methods are particularly appropriate to capture the social meanings of these issues (cf. Secor, 2003). The focus group guide was designed to query senses of environmental activism and citizenship and to highlight which environmental issues participants felt were important for their own cities and for Turkey as a whole. Focus groups also used novel techniques such as photo elicitation; a halfdozen images were shown to participants without explanation at the beginning of the session to break the ice and encourage conversation. Participants were asked to discuss and respond to the images-a set that included an agricultural scene, a forest with what appeared to be some logging, a dam reservoir, and flamingos off of Turkey's Aegean coast. The author coded the full set of transcripts for key themes, as detailed in the results section below.

The Istanbul focus groups were carried out by the Sosyal Arastirma Merkezi (SAM, Social Research Center) and drew randomly from the center's database of over 10,000 residents (two focus groups were held with men over the age of eighteen, one with women). Focus groups in the southeast were more informal and were largely organized with the help of local non-governmental organizations and through social networks (e.g. one working on women's livelihoods and another working with recent migrants to Diyarbakir). ${ }^{\text {vi }}$ Thus, the participants in the southeast were more likely to know each other, while those in Istanbul were strangers to each other. Kurdish speakers were a majority of the participants in the southeast, and a subset of the Istanbul participants.

The inclusion of two southeastern sites is a significant element of the research design, with clear implications for the results presented. Diyarbakir is the primary city of Turkey's Kurdish region and has been the epicenter of both activism and violence of the past several decades. Sanliurfa is a fast-growing city that is home to many Kurdish- and Arabic-speaking minorities. As highlighted in the discussion below, including southeastern sites enables explicit exploration of salient socio-spatial divides in the contemporary Turkish context (e.g. East-West, rural-urban, Kurdish-Turkish). 


\section{KEY THEMES FROM LAY ENVIRONMENTAL NARRATIVES IN CONTEMPORARY TURKEY}

Iterative analysis of the full set of transcripts revealed five central themes. First, when discussing the environment, respondents often convey a sense that social and ecological issues are fundamentally linked. Second, respondents frequently highlight social and spatial differences. Third, respondents particularly emphasize East-West gradients both within Turkey (e.g. East-West, Kurdish-Turkish) and also more generally (i.e., Turkishness-Europeanness). Fourth, emotional and affective references permeate environmental narratives. This is in part due to the "social" dimensions (the first theme) as well as to emotionally and politically charged issues that map along East-West gradients (the third theme). Fifth, building on all of the above, environmental narratives in contemporary Turkey suggest a deep ambivalence. In the following subsections, I discuss all five themes and their intersections but focus especially on the third-EastWest differences.

\section{(1) Cevre, integrated social ecological understandings}

As has been discussed elsewhere (see Author 2011), the word cevre is commonly used for "environment" and may be translated literally as "surrounds." Exchanges about environmental issues or how one views environmentalists (cevreci) often moved fluidly between the "social" and "ecological;" "vii for instance, respondents mentioned insensitive neighbors who rudely beat their carpets on their balconies or who throw trash on the streets. These behaviors clearly affect one's surrounds, although they may not be readily identifiable for all as environmental issues. I have argued elsewhere that this focus on everyday, local-scale concerns has the potential to mask other broad-scale, less-visible environmental challenges such as climate change or pollution (ibid). As I further explore below, respondents also emphasized other elements of social context in ways that broaden discussions of environmental imaginaries and movements.

\section{(2) Social and spatial difference}

A second theme relates to social and spatial differences, including religious, class, and geographic divisions (several of which are already documented in the literature). viii For instance, respondents invoked Islamic imperatives to keep oneself or one's neighborhood clean: "cleanliness comes from faith," "Islam is cleanliness," and

"a man of religion doesn't pollute. A Christian wouldn't pollute, and a Muslim wouldn't pollute. Cleanliness is from faith, it is at the heart of all religions."

In addition, there were class associations with environmentalists (cevreci) as being well- 
educated, as well as positive expressions of environmentalists as selfless, moral, and committed to the places where they live. For instance, "educated people throw trash into a trash can, uneducated people throw trash on the ground. .ix

In terms of ways that environmental imaginaries were linked to notions of difference that are less well characterized in the literature, respondents also frequently mentioned urban and rural divides. As noted above, focus groups were shown several visual prompts without explanation. Among the images that garnered the most spirited reactions was that of an elderly woman collecting water from a frozen lake using an cooking oil tin (most likely taken in the Black Sea region or eastern/southeastern Turkey, see Image 1); ensuing conversations highlighted both urban-rural and EastWest gradients.

Common-and telling -responses to this image included disavowal, sadness and regret. As one Istanbul focus group participant expressed, "I do not think that backwards places like that exist today in Turkey." Immediately, others chimed in: "Var, Var" ("Yes there are! Yes there are!"). Another participant interjected forcefully: "Does not the east belong to Turkey?" In brief, the woman and space represented in this image reflects the ongoing challenges of achieving Turkish modernity, as well as the linked desire to cast off certain regions or lifeways associated with Turkey's past (consider modernist ideas associated with Kemalism, see Bozdogan and Kasaba 1997; Harris, 2008; Atasoy 2009). The woman's reliance on her environment (accessing water from a lake) creates a sense that too close of an association with nature is likely to be unhealthy and indeed, even unimaginable in the space of modern Turkey. Other focus group participants responded to this image by expressing sadness and shame; one called it "Yazik" (a shame/pity), others declared it "unacceptable," and another called on the state to meet its long-standing promise of modernity for all of Turkey's residents: "if poverty like this exists, it is the shame of our state."

This image also spurred discussions that echoed hierarchy of needs discussions to query whether people facing impoverishment are capable of environmental care. As one example:

"if you are poor, you cannot take care of yourself...your spirit is broken... you are psychologically challenged. A person may be poor so he goes to the forest and cuts down trees. Why isn't the forest in Europe degraded?"

This statement reinforces the belief that impoverished populations encounter difficulties in caring for the environment. It also invokes particular conceptualization of Europeanness, also mobilized in other remarks:

"In Europe, twenty to thirty men and women get together and clean up a beach. Here if you do something like that you would starve. We don't have the right 
conditions to do something like this here, people are concerned about earning their bread...They are concerned about bringing home food to their children. People neither have time nor resources to do these kinds of activities."

While poverty was often presented as a barrier faced by rural residents in being environmentally sensitive, there were also counter-narratives: rural spaces were also characterized as a strong ethic of environmental care based on villagers' posited connections to the land, to the seasons, and to each other. This view was perhaps most forcefully asserted in an interview with leaders of an NGO focused on agricultural sustainability; they insisted,

"our roots, our core is rural...We just need to strengthen our roots, then we can have a connection (to nature) again."

Other statements echoed these ideals: "villagers are more devoted to green" or "it is easier to make people understand in the village." Such language celebrates agricultural and rural spaces and lifeways, suggesting they are more sustainable precisely due to senses of amodernity, minimal consumption, and lack of connections to other locales (similar valorizations exist in other contexts, such as North American "back to the land" movements; see Guthman 2004).

Other narratives of rurality invoked senses of melancholy and loss. We can perhaps make sense of this given the intensity of rural-to-urban migration in Turkey since the 1950s. Given this common migration pathway, a sense of "loss" likely also relates to the strong identification of many with their natal or familial village; indeed, it is common to return for holidays and to refer to oneself in relation to one's natal village. ${ }^{x}$ In these ways the rural can be understood as standing in as a proxy for home, and for being in a place where on is familiar, and among family (see special issue on the importance of hometown associations in Turkey, Hersant and Toumarkine 2005). Given the linked socio-ecological understanding of environment (explored above), it is also understandable that focus group discussions often moved seamlessly between discussions of spaces or surroundings in which one is familiar, where one belongs, and where one experiences a sense of care; while posing contrasts with spaces where aspects of the social or ecological surrounds may be less familiar, less welcoming, and less marked by an ethic of care. These ideas were variously mapped against spaces of the rural and urban, or of the east and west.

Diyarbakir respondents, several of whom had experienced violent displacement from their natal villages as part of forced evacuations related to the Kurdish conflict, spoke to issues of environmental care with a strong accent on the idea of loss. These respondents recalled how their orchards were burned as part of state anti-terrorism campaigns. Asking what it means to care for the environment when they cannot even tend to their fields and orchards that were burned by state agents, these participants 
offered a direct challenge to what might count as environmental stewardship. For them, violence and forced displacements had made it impossible to care for crops, natures, and landscapes.

Providing points of contrast to portraits of the rural, focus group participants commonly presented urban spaces as hostile, isolating, and lacking social or familial connections. As one expressed,

"the things that happen in Istanbul do not happen in rural regions. There are so many things that make me sad in Istanbul."

Another stated,

"Seventy-two millet (peoples or nations) live together in Istanbul. You cannot expect different people to crowd together and get along."

Here, the respondent is speaking directly to the mix of ethnic groups and the difficulty that such diversity brings to urban living. The built environment (e.g. cement buildings and paved streets) was also frequently cast as contributing to a sense of alienation. The list of environmental problems noted by focus groups participants included: lack of green space, betlonlastirma (extreme construction or the paving over of things), and air and noise pollution (see also Author 2011). These mappings of the urban and rural, including the ambivalent and emotive associations, demonstrate key elements of imaginative geographies of green-particularly notions of social and spatial difference that are central to these imaginaries.

\section{(3a) East-West gradients within Turkey: Kurdishness and spaces of the southeast}

As I have already noted, the research design expressly targeted East-West gradients (for instance, by including southeastern sites and associated mappings of underdeveloped-developed or Kurdish-Turkish). Reactions to the image depicting a woman collecting water from a lake, the narratives of violence around Diyarbakir, the east's portrayal as excluded from modernist and developmentalist imaginaries (Bozdogan and Kasaba 1997; Dahlman 2002, 2004; Harris 2008), are all discussions that hinge on, and accent, East-West divides.

When considering other dimensions of this gradient, it is critical to note that formal associationalism was outlawed in the southeast for several decades during the height of the Kurdish conflict, with strong enforcement of bans on political expression and demonstration (Harris 2002, 2008; Dahlman 2002, 2004). The comment of an activist in Diyarbakir puts this issue in perspective: "OK, the environment is important, but for us to survive is more important." Another Diyarbakirli responded "participating in civil rights organizations still builds fear in people...I think this is the difference of Diyarbakir." The Kurdish conflict and the region's violent history are clearly central to understanding 
contemporary green visions and movements, with the threat of jail time for meeting together or demonstrating continuing to cast a long shadow on possibilities for contemporary mobilization or associationalism (see Harris 2002). These embedded geographies and histories also challenge the common discourses about NGO capacity in the Kurdish-dominated southeast as lagging or underdeveloped-a characterization that is common to the literature and is also foregrounded with focused EU investment for civil society development in the region. ${ }^{\text {i }}$ I now turn to broader scales of East-West that were invoked in discussions of environmental issues and capacities, specifically that of "Turkey"/"Europe").

\section{(3b) East and West without Turkey: Turkey and Europe}

As examined above, respondents often invoked Europe to signify developed, environmentally active, or clean spaces to Turkey's west -and positioned Turkey, by contrast, as relatively backward, less developed, or as having to follow Europe's example. Expressions of this type might be anticipated, whether stemming from "hierarchy of needs" or "ecological modernization" ideas or from media attention to strong environmental associations and movements in places such as Germany or Sweden (see endnote 3, e.g., Lafferty and Meadowcroft 1996; Gleditsch and Svedrup 2002; also recall discussion of Gerhards and Lengfeld 2008, above). It is noteworthy that, although the questions asked about the EU in focus groups were few and posed towards the end of the sessions, Europe and the "West" were "always there" as an absent referent (Chakrabarty 2000). It must be restated that these associations are not new and, indeed, must be understood as part of long-standing Orientalist (Said 1978) representations of Europe as a space of desirability and progress and of Turkey as its amodern "Other"-narratives that find vivid and continuing expression in EU accession debates (Rumelili 2007; Ramm 2009). As we consider these discourses, there is a clear need to attend to these cultural-historical and political lineages (Gole, 1996; Zurcher 2005a, 2005b; Harris, 2008; Atasoy 2009). As well, even as these ideas might be anticipated, their repeated invocation is nonetheless significant.

Similar to the belief that impoverishment necessarily places more immediate needs before environmental care, respondents frequently referenced an inevitable absence of strong environmental capacities and citizen subjectivities in Turkey. In these accounts, environmentalism will come only after priorities such as education, literacy, or unemployment have been addressed; for instance, one respondent demanded,

"If you don't understand, how can you be sensitive... how much environmental consciousness can there be in an illiterate society?"

In at least one NGO interview, the idea that pollution is necessary for progress was spotlighted as contributing to a sense that environmentalism is not possible. This framing situates environmental degradation as inevitable — part and parcel of progress- 
and environmental advocacy as therefore impeding much-needed and long-awaited economic development (see Adaman and Arsel's 2005 discussion of ecological modernization). As one activist explained, some believe that Turkey can pollute the environment, make money, and worry about rehabilitation later-just as Europe did. If the summer 2013 protests sparked by the development of Gezi Park in Istanbul are any indication, however, this attitude is not necessarily widely shared. The demonstrations and subsequent events have had tremendous political and economic ramifications across the country-with tensions of environment and development at center stage in ways that highlight the precise type of issues explored here.

Many other respondents went beyond political-economic explanations, relying instead on the language of culture in ways that suggest the internalization of long-held Orientalist tropes. One focus group participant mentioned that the culture in Turkey is problematic and that people "cut young trees" without knowing the consequences. Some Istanbul respondents offered: "we do not understand the language of nature" and "environmental consciousness is low in us, this is a matter of culture... we were barbaric as kids." Participants in the focus group for environmental leaders in Diyarbakir also invoked the "weak environmental culture" in Turkey and in the southeast in particular (see also Author 2011). These portrayals mirror the classic move described so well by Said (1978) by referencing "weak" environmentalisms in Turkey, there an implicit or explicit reference to "strong" or "normative" green practices and environmentalism elsewhere. Europe, in particular, provides a counterpoint to Turkish backwardness or even barbarism. Consider: "Europe is more orderly, more green," "rich people don't pollute," and

"my friend who lives in Germany says that the streets are very clean.... People in Europe protest if you throw trash. Here, we don't do that."

One woman in Diyarbakir elaborated:

Europe attracts my attention. Especially in cities the green areas are more orderly. $B e$ it on the sides of the roads, or around stadiums, the green areas are more tidy... But we don't take care of the vast areas that we own.

Another participant underscored the opportunities for activism made possible by greater freedom of expression and political freedoms:

"The European can show a reaction, he can handcuff himself (to a tree) and make a press release. It is not like that in our country."

An older Kurdish speaking woman in Diyarbakir similarly put an accent on the links between human rights, political expression and environmental ethics:

"[Europe] attaches importance to everything-to humans, they attach importance to 
the environment...If people are made aware (conscious) then they protect everything...As far as I have heard, there if you hang clothes on the balcony [in Europe], there is a fine."

Not surprisingly, especially in the Kurdish southeast the tension between environmental values and other concerns was often emphasized (e.g. human rights, violence, impoverishment).

Respondents also frequently referenced European regulatory conditions that make an ethic of care possible, or even mandatory. Late in focus group discussions we also asked directly what full membership in the EU might mean for Turkey. One participant responded that "if we joined the EU, it would be more beautiful, it would be a tidier country," another added "It would be an orderly country," while a third interjected, "an orderly citizenry." As is clear, East-West gradients and ideas of "Europe" and "Turkey" map against environmentalisms and visions of green in complex and contradictory ways. As well, as the contestations sparked by the Gezi park protests make clear, these mappings are also dynamic and constantly negotiated.

\section{(4) Emotions and affect}

The emotional charge of these issues is evident from a range of exampleswhether discussions of who appropriately belongs to Turkey, or references to the sadness and trauma of lost village life and forced migration. Resonating with other recent work (e.g., Sharp, 2008; Pile 2010), there is a clear need to theorize emotions more centrally as a key feature in social science work of this type. Indeed, several scholars have recently argued that emotions are particularly meaningful in thinking about emergent politics, including what motivates political protest (e.g. a sense of injustice, anger, or spiritual attachment; see Woodward and Lea 2010; Wright 2010). Nature-society contributions-including several from political ecology-have similarly spotlighted emotional and affective dimensions of resource use and access as a particularly salient issue (Satterfield, 2008; Nightingale 2011; Sultana 2011).

One female participant's response to an image of what she interpreted to be a partially degraded landscape helps to illustrate this point:

"this picture conjures up complicated emotions for me. The surrounding area is very peaceful, but in the middle it is complicated, this reflects human emotions."

Another participant added: "this feels like a mistake, it feels wrong." A more decisive statement in another discussion highlighted a sense of frustration and injustice in the face of values seemingly imposed by neighboring Europe:

"Europe talks so much about ecology, but for whatever reason, they bring all their chemical wastes and throw them on us. Since you have such a high consciousness, such a civilized society, this is not humane. Why do you throw 
those chemical wastes in the middle of the sea. You destroy living things in the sea, shouldn't this be discussed too?"

These quotes demonstrate that engaging with environmental issues, and with expectations and visions of green, elicits various feelings of longing, desire, inadequacy, loss, sadness, or injustice. The respondents identify strong emotions, but also articulate deep ambivalence-the last theme of interest.

\section{(5) Ambivalence}

Returning more centrally to several of the postcolonial analytics highlighted in the introduction, ambivalence helps to think the implications of the contradictory expressions that emerged. To recall several such ambivalences, urban spaces in Turkey were cast both as more environmental (due to wealth, education, or levels of civil society engagement) and also as hostile spaces in which one feels less of an obligation to surrounds (due to built architecture, lack of green spaces, and lack of social connectivity); rural spaces were at once portrayed as impoverished, backward, and inimical to environmental care yet also as spaces of holistic environmentalism in which one is connected to both social and ecological surrounds (through seasons, livelihoods, or senses of belonging in a familial context).

Turkey-Europe divides are also marked by similar contradictions and ambivalences. For instance, many respondents called for European-style fines and regulations to encourage more environmentally responsible behavior. One activist from Diyarbakir lamented:

"If we compare with Europe ...for a recycling project the (federal) state (in Germany) allocated 1.8 million Euro as part of the budget. This was a separate budget made available by the state. This is a state policy, and a (example of the) state doing what it is supposed to do. But we don't find this in Turkey. We have laws. But for these laws to take effect, neither government agencies nor investors are given enough support. Or maybe when the laws are issued, they are ignored."

Yet, even as many cited the need for proactive state regulation and levying fines, Europe's legal and institutional landscape was also portrayed very negatively-as too regulated. In speaking of Europe, one respondent invoked the word ruhsuz-a term for something lacking in vitality or spirit. Others alluded to sterility, with one person stating directly that if Turkey were to join the EU,

"it would ensure that everything is sterile. Everything would be done according to the EU—they would determine everything."

To make sense of this ambivalence, it is instructive to consider other features of EU accession debates. Providing one illustration, geographer Paul Kaldjian (2008) notes the anxiety and public outcry that followed rumors of a possible ban on the sale of 
kokoreç (a beloved Turkish street food of stuffed lamb intestines) to conform with EU sanitary directives. It seemed that nothing short of Turkish culture and the taste of food was at stake. Focus group discussions similarly revealed a sense that aligning Turkish environmental regulations with those of Europe might lead to losses of Turkish spirit, culture, and lifeways. Highlighting that Turkey should not endeavor to become more like Europe, people made comments such as "people who have everything suffer a psychological emptiness, nothing comes beautiful to them, they are dissatisfied with life," "Yes, they have beautification campaigns, but what else do they have?", and "our moral values are superior to Europe, if people are poor, their moral values are good." One respondent similarly highlighted the extremity of European regulations, speaking as part of the focus group discussions about her relatives being deported "for picking flowers." Other respondents directly challenged a sense that Turkey needs to conform to EU expectations in other ways; one amca (uncle) interviewed in the rural southeast elaborated:

"Let me tell you something. You said democracy. They [Europe] got democracy from us, now they are selling it back to us."

In a separate discussion, another amca stated (this time discussing the United States):

"They learned how to take a bath from us. Now we forgot our past, how we can clean our houses, and how to be sensitive about the outside too."

Homi Bhabha foregrounds (1994) such ambivalences as a core feature of the colonial encounter. At once, we see that Europe is a model for Turkish environmentalisms, but there is also deep ambivalence as this proceeds with a parallel sense of desire, longing, loss, and frustration. There is value placed on Europe and Europeanness, while also a celebration of Turkish traditions and practices, resistance to European-style regulation, or expression of sadness that Turkish practices and lifeways might be lost or regulated away. Yet again, it is worth reiterating that these sentiments do not stand in isolation, and do not refer solely to the environmental realm. Indeed, the narratives cited throughout this paper must be read against the broader history of Turkey-EU (or Ottoman-West) relations as well as against a contemporary media and political context in which questions related to Turkey's fitness, readiness, and acceptability for integration in Europe circulate on a daily basis.

By referencing these tensions and by learning from aligned postcolonial concepts, the analytic of imaginative geographies of green invites us precisely to consider the power-laden relations and contextual considerations through which diverse environmentalisms might emerge or be contested-particularly the extent to which they rely on Orientalist and colonial pathways and logics. It is through such a reading that we can appreciate the complex ways 'green is read and the complex politics and histories that are necessarily evoked in these discussions. Just as there is a sense of loss in 
moving from village spaces where one is connected to landscapes, to seasons, and to social surrounds, to hostile or unfamiliar urban spaces of Istanbul or Ankara, there is perhaps a parallel sense of loss with movement from an endemic and culturally aligned ethnic of care to one that is in step with environmentalisms. This may mean shifting from an endemic (or culturally appropriate) ethic of green to an ethic of care imposed from above or from without (whether through regulation or through fundamentally different cultural norms). Here we see a clear a desire for replication (mimicry), but also sadness that such mimicry will never quite be realized, or that doing so would mean loss of values or diminished sense of cultural or religious traditions in a context such as Turkey. Huzun speaks directly to these issues-when Europe is taken as the model for green values and politics, and when Turkish culture and lifeways are relegated to a peripheral position—recalling refrains that are all too familiar for Turkish culture and politics.

\section{CONSEQUENCES, EFFECTS, CONCLUSIONS}

What is the significance of these varied and ambivalent expressions for environmental conditions and possibilities? Particularly given emotional and affective dimensions, what might be the significance for what types of environmentalisms or visions of green might emerge, or be resisted, in this context? I offer both empirical and theoretical conclusions.

\section{Empirical Conclusions: Environmental possibilities, the EU, and democratization}

If urban spaces are seen as necessarily degraded and alienating landscapes, then residents may not feel the same sense of responsibility to surrounds (both natural and social) as compared to rural spaces. Urban environmental politics in might therefore look very different from rural mobilizations (see Adaman and Arsel 2005 for a discussion of varied Turkish environmentalisms). Furthermore, East-West social-cultural associations (including those linked with Turkishness or Kurdishness) could affect regionally differentiated green movements and politics. For instance, the fact that environmental NGOs and associations are less visible in Turkey's eastern regions (ibid); may result from developmental gradients (as is often assumed), but also may be conditioned by other aspects of imaginative geographies of green in line with the issues explored here.

Similarly, discursive connections between environmentalism and Turkey-EU debates (and related tensions therein) might also have considerable consequences for activism. For example, we might see resistance to mobilization in the name of 'European values' or concurrent valorization of Turkish nationalist or religious identities 
(cf. Kubicek 2005). As such, there may be resistance to an embrace of European "order", "cleanliness" and "regulation" this also means shedding Turkish culture and lifeways (as connoted with the term ruhsuz or the threat to the beloved kokoreç). In several NGO interviews, discussion turned to the sense that Europe was expecting Turkey to give up too much as part of the accession process; several activists stated that perhaps it was best for Turkey to go through the process (there was recognition that it had opened up new political possibilities and spaces for change), ${ }^{\text {xi }}$ but in the end it might be better for Turkey (and for the environmental movement specifically) if Turkey is not accepted for full membership. The risk, they implied, would be that Turkey will be put in the position of forever trying to comply with EU expectations and will be forced to shed modalities that might be more consistent with Turkish history and culture.

The insights gleaned from exploration of imaginative geographies of green may also help to explain changing popular views on the possibility of EU accession. Data collected by Eurobarometer, which tracks public sentiment related to the EU accession process, has shown a precipitous decline in recent years, with support dropping from over 60 percent support in 2004) to less than half (45 percent) of Turkish citizens in 2009 (Eurobarometer 2010). The examples provided here help us to better understand why such resistance might be growing. As well, the empirical exploration offers textured detail in a way that contributes to the stated imperative to better understand shifting identities and meanings associated with 'Europe' and 'EU' practices, including complex negotiations of "Eastness"(Kuus 2007; Firat 2009) and to consider how the EU might be anticipated by diverse publics (Visier 2009).

\section{Theoretical Conclusions: Southern environmental citizenship and politics, postcolonialism, and affect}

Theoretically, one conclusion from this work is to argue for the need to pursue more qualitative and context-focused work to attend to the ways that green politics and movements are interpreted, read, and hold meaning in everyday lives. ${ }^{\text {xiii }}$ The case study presented here suggests forcefully that we cannot adequately address the possibilities for emergent environmentalisms without attending to the contextually and historically specific meanings attached to green politics and movements. For many sites in the global South, these meanings are likely to intersect with colonial logics and pathways in important ways. The concept of imaginative geographies of green helps to tease out and emphasize such mappings (particularly those related to socio-spatial difference and attendant postcolonial connections), to more comprehensively analyze topologies through which environmentalisms are constituted and contested (Brosius 1999), and to enrich our appreciation of how environmentalisms make sense within wider circuits of meaning and with respect to historical antecedents (Paley 2002).

Moreover, the study makes it very clear that environmental citizenship, identities and subjectivities are complex, and these linked processes that necessarily play out in a 
charged political and social terrain. Further work is needed to conceptually map this terrain, including associations with identity and difference (see also Latta 2007; Gabrielson 2008; Grove 2009; Author 2011) and broader power dynamics (Birkenholtz 2008; Grove 2009; Wong and Sharp 2009). I amplify these calls and argue that recent appeals in socio-cultural geography-including ongoing need for closer engagement with postcolonial scholarship as well as enriched attention to emotion and affect-offer particularly promising orientations for future work. Postcolonial analytics, in particular, hold tremendous potential for understanding nature-society processes and movements (cf. Willems-Braun 1997; Wainwright 2005; Robbins 2006). The analysis from Turkey offered here lends weight to Willems-Braun's assertion that nature is never a "pure" category but is always embedded in social histories and that "colonial histories and neocolonial rhetorics continue to infuse 'common' sense categories and identities regarding nature and resources'" (Willems-Braun 1997, 4). By examining environmental politics and meanings from outside the metropole and beyond formal and expert realms of "science," the "state," and "geopolitics," this contribution also broadens our understanding of the conceptual spaces of "nature" and "green politics" to illustrate that repeated failures to critically interrogate these categories serves to perpetuate and reify colonial logics and pathways. The results also demand that we confront the elemental question of what we understand as appropriately "environmental" in discussions of green politics, citizenship, and subjectivities. Several respondents gave voice to this critique directly-offering a pointed response to the types of discourses about needing to catch up to the West that remain central to the large body of work on Southern environmentalisms (again recall the examples in the introductory section that suggest lagging environmentalisms and the need to promote environmental identities and civil society in contexts such as Turkey). Recalled Pamuk's vivid autobiographic reflections, we can also ask: what does it mean if our scholarship imposes a particular vision of "green" on the rest of the world? Moreover, what might it mean to create space for more culturally contingent and contested notions of "green"-particularly to allow for culturally consistent or endemic forms that might be more amendable in varied contexts?

A linked theoretical conclusion relates to the promise of postcolonial and emotionalaffective insights for scholars of environmental citizenship and environmentality more specifically (Agrawal 2005; Dobson and Bell 2006). Although these literatures are primarily concerned with "what makes someone identify with environmentalism" or come care about green issues, debates therein have proceeded largely without attention to these concepts and tools. Attention to contextually specific associations of green, and to the ambivalent relationship that many might have to other visions and movements, is likely crucial to explain how and why certain issues do or not gain political traction and meaning. Foregrounding postcoloniality, emotion, and affect could also go a long way towards correcting over-focus on rationality and "environmental education" in these discussions-particularly in light of mounting evidence that better 
information and education bears no clear relationship to behavioral change or environmental outcomes (e.g., Robbins 2007; Ignatow 2008b). Emotional-affective associations are likely to tell us a great deal about such disconnections.

We end full-circle with a return to hüzün. Drawing attention to the loss and sadness associated with peripherality or with the expectation of following the example of Europe and the West, this term captures the emotional toll of longing for, and inevitably failing to achieve replication. In this way, hüzün captures many of the ambivalent, power-laden, and emotional expressions that were clear to narratives of everyday environmental issues in contemporary Turkey as revealed by this research. Again, many expressed the sense that Turkey needs to change and adopt more European style ethics or regulations; however, many also associated movement towards Westernstyle environmentalism with the possibility of loss. Beginning to address and unpack these ambivalent and emotive imaginative geographies can greatly enrich our understanding of environmental politics, movements, and subjectivities. As well, speaking to a broader project of decolonizing nature-society studies, it seems clear that such understanding offer a clear starting point to guide efforts to "unmap" or rewrite nature-society geographies in ways that attend to and refute colonial logics, optics, and imaginaries associated with colonialism (Razack 2002; Sparke 2007; Spivak 2008). Given the centrality of social and spatial differences to these imaginaries, cultural, social and political geographers inquiry, in particular, appear to have a clear role to push forward this line of inquiry and critique.

Notes: ${ }^{i}$ I do not distinguish between these concepts even as other theorists might use "emotion" to refer to the cognitive realm and "affect" to refer to subconscious or embodied relations (see Pile 2010; Gregg and Seigworth 2010).

ii Maslow's "hierarchy of needs" thesis (Gardner 1995; Mawdesley 2004; Ignatow 2005) and ideas of "ecological modernization" (e.g., Buttel 2000; Adaman and Arsel 2005) are central to much of the research on Southern environmentalisms.

iii The research also included review or Turkish language sources, including several MA and PhD theses on relevant themes.

iv The authors focus on one question from Gallup International Millennium Survey that they suggest operationalizes the core idea of EU environmental policies: "Which of the following statements do you agree with more? (1) It is more important to protect the environment than to ensure economic growth. (2) It is more important to ensure economic growth to protect the environment (3) Don't know."

" The EU has invested millions of Euros environmental NGO and "civil society" capacity building (one of eight target areas). Elsewhere, I have dealt more explicitly with accession processes' effects for Turkish politics (Author 2011; see also Kubicek 2005 for EU processes and civil society in Turkey; Kousis 2004 on Southern Europe; Atalan-Helicke 2011 for changing Turkish agricultural practices).

${ }^{\mathrm{vi}}$ In terms of the politics of these organizations, the migrant-related NGO can be understood as very political with respect to the Kurdish issue. The politicized nature of the narratives is clear from the data presented. The women's atelier group also involved Kurdish speaking women, but the NGO itself is more focused on economic and livelihood concerns. Quotes from the third group-with environmental leaders and activists-are clearly identified throughout. It is also worth mentioning that Diyarbakir as a research 
site in itself is political, given that a range of contestations are very central to the urban fabric there (i.e. responses would be quite different if we targeted an Aegean site, or a city such a Konya). Focus groups in Urfa and Istanbul were more of a 'random' sample in terms of a range of political issues.

vii There are other words that have slightly different connotations, for instance, doga is more consistent with the English term "nature" and tabi and tabiat is an older, more poetic term that might be translated more as "natural" or "essence" Each of these terms appears in the titles of some of the well-known NGOs dedicated to environmental issues (and also can be used to refer to 'environmentalists, e.g. cevreciler, dogaciler, yesilciler).

viii Others have suggested that certain religious groups may be associated with environmental care (e.g., Pusch 2005; Ignatow 2008a).

${ }^{9}$ It is worth noting that similar expressions have long been present in discussions of modernity in Turkey, including discussions of civility or modernity linked to Kemalism (Aydin, 2006; Harris, 2008).

${ }^{x}$ A very common question in Turkey "nerelisiniz?" ("Where are you from?") It is often answered with one's natal village (e.g., for Urfaliyim, "I am from Urfa", or for Eskisehirliyim, "I am from Eskisehir").

${ }^{x i}$ According to the European Union website (2013), investment foci include civil society, disadvantaged and vulnerable groups, and the environment. This was also confirmed in interviews with NGOs throughout the southeast and across Turkey. Specific funding has also targeted civil society development in the Southeastern Anatolian region (Author, 2011).

xii Several very important legal changes include changes to the laws regulating "associations" (dernek) in Turkey (2007 interviews, also discussed in Izci 2005, 33). Constitutional amendments under consideration are expected to have profound political and associational implications.

${ }^{x i i i}$ For example, as Turkish activists noted on several occasions, a short-lived green party and environmental manifesto did not seem to capture the imagination of people in Turkey. Furthermore, while Turks indicate high degrees of environmental interest on national surveys, they generally exhibit low levels of participation in formal environmental organizations (Adem 2005). Attention to meanings and context helps to unpack these complexities. Research of this type also raises some potentially interesting issues for democracy theory-such as how EU-encouraged civil society development might affect debates concerning grassroots democracy (cf. Kubicek 2005; Tocci 2005). 


\section{REFERENCES}

Adaman, F., and M. Arsel, eds. 2005. Environmentalism in Turkey: Between democracy and development? Aldershot, UK: Ashgate.

Adem, C. 2005. Non-state actors and environmentalism. In Environmentalism in Turkey: Between democracy and development?, eds. Adaman, F., and M. Arsel, 67-84. Aldershot: Ashgate.

Agrawal, A. 2005. Environmentality: Technologies of government and the making of subjects. Durham, NC: Duke University Press.

Agyeman, J. and B. Evans. 2006. Justice, governance, and sustainability: Perspectives on environment citizenship from North America and Europe. In Environmental Citizenship, eds. Dobson, A., and D. Bell, 185--206. Cambridge, MA: MIT Press.

Alatout, S. 2006. Towards a bio-territorial conception of power: territory, population, and environmental narratives in Palestine and Israel. Political Geography 25 (6): 601-621.

Atalan-Helicke, N. 2011. The seeds of change: the state, the politics of development, and conservation in neoliberal Turkey. PhD Thesis. 271. Dept of Geography, Ohio State University.

Atasoy, Y. 2009. Islam's marriage with neoliberalism: State transformation in Turkey. New York: Palgrave Macmillan.

Aydin, C. 2006. Between occidentalism and the global left: Islamist critiques of the West in Turkey. Comparative Studies of South Asia, Africa and the Middle East 26 (3): 446-461. 
Bhabha, H. 1994. The location of culture. London: Routledge.

Birkenholtz, T. 2008. Groundwater sector: divergent environmental knowledges and subjectivities. In Contentious geographies, eds. M. G. M. Boykoff and K. Evered, 81-96. Aldershot: Ashgate.

Bozdogan, S., and R. Kasaba, eds. 1997. Rethinking modernity and national identity in Turkey. Seattle, WA: University of Washington Press.

Brosius, P. 1999. Analyses and interventions: anthropological engagements with environmentalism. Current Anthropology 40 (3): 277--309.

Buttel, F. 2000. Ecological modernization as social theory. Geoforum 31(1) :57--65.

Chakrabarty, D. 2000. Provincializing europe: Postcolonial thought and historical difference. Princeton, NJ: Princeton University Press.

Dahlman, C. 2002. The political geography of Kurdistan. Eurasian Geography and Economics 43(4): 271-299.

Dahlman, C. 2004. Turkey's accession to the European Union: The geopolitics of enlargement. Eurasian Geography and Economics 45 (8): 553--574.

Davis, D. and E. Burke. 2011. Environmental imaginaries of the Middle East: History, policy, power, and practice. Athens, $\mathrm{OH}$ : Ohio University Press.

Dobson, A. and D. Bell. 2006 Environmental citizenship. Cambridge, MA: MIT Press. 
Escobar, A. 1995. Encountering development: The making and unmaking of the Third World. Princeton, NJ: Princeton University Press.

Eurobarometer. 2010. Eurobarometer data. http://ec.europa.eu/public_opinion/archives/ (last accessed 14 May 2010).

European Union. 2013. http://ec.europa.eu/enlargement/instruments/funding-bycountry/turkey/index_en.htm (last accessed July 13 2013).

Firat, B. 2009. Negotiating Europe/Avrupa: Prelude for an anthropological approach to Turkish Europeanization and the cultures of EU lobbying in Brussels. European Journal of Turkish Studies. http://ejts.reveus.org/index3794.html (last accessed 14 May 2010).

Gabrielson, T. 2008. Green citizenship: A review and critique. Citizenship Studies 12 (4): 429--446.

Gardner, S. S. 1995. Major themes in the study of grassroots environmentalism in developing countries. Journal of Third World Studies XII (2):200-244.

Gerhards, J., and H. Lengfeld 2008. Support for European Union environmental policy by citizens of EU-member and accession states. Comparative Sociology 7 (2): 215-241.

Gleditsch, N. P., and B. O. Sverdrup. 2002. Democracy and the environment. In Human Security and the environment: International Comparisons, eds. Page, E., and M. Redclift, 45--70. Cheltenham, UK: Edward Elgar Publishing.

Gole, N. 1996. The Forbidden Modern: Civilization and Veiling. Ann Arbor, Ml: University of Michigan. 
Gregg, M., and G. Seigworth. 2010. The affect theory reader. Durham, NC and London, UK: Duke University Press.

Gregory, D. 2004. The colonial present: Afghanistan, Palestine, Iraq. Malden, MA: Blackwell.

Grove, K. 2009. Rethinking the nature of urban environmental politics: Security, subjectivity and the non-human. Geoforum 40 (2): 207--216.

Guha, R. 1989. Radical American environmentalism and wilderness preservation: A third world critique. Environmental Ethics 11:71--83.

Guha, R. 1997. The authoritarian biologist and the arrogance of anti-humanism: Wildlife conservation in the Third World. The Ecologist 27 (1): 14--20.

Guthman, J. 2004. Agrarian dreams: The paradox of organic farming in California. Berkeley, CA: University of California Press.

Haggerty, J. H. 2007. "I'm not a greenie but..." Environmentality, eco-populism and governance in New Zealand: Experiences from the Southland Whitebait fishery. Journal of Rural Studies 23 (2): 222-237.

Harris, L. M. 2008. Modernizing the nation: Postcolonialism, (post)development, and ambivalent spaces of difference in southeastern Turkey. Geoforum 39 (5): 1698--1708.

Harris, L. M. 2002. Water and conflict geographies of the Southeastern Anatolia Project. Society and Natural Resources 15 (8): 743--759.

Haynes, J. 2009. Power, politics, and environmental movements in the third world. Environmental Politics 8 (1): 222--242. 
Hersant, J., and Toumarkine, A. 2005. Hometown organisations in Turkey: an overview. European Journal of Turkish Studies, Available online : http://ejts.revues.org/359 (Last Accessed July 18, 2013).

Huggan, G., and H. Tiffin. 2007. Green Postcolonialism. Interventions 9 (1): 1--11.

Ignatow, G. 2005. Economic dependency and environmental attitudes in Turkey. Environmental Politics 14 (5): 648--666.

. 2008a. Transnational environmentalism at Europe's boundaries: Identity movements in Lithuania and Turkey. Current Sociology 56 (6): 845--864.

.2008b. Schools, science and the social bases of global environmentalism: An institutional analysis of environmental organizations and worldviews. Saarbrucken, Germany: Verlag.

Izci, R. 2005. The impact of the European Union on environmental policy. In Environmentalism in Turkey: Between democracy and development?, eds. Adaman, F., and M. Arsel, 87--100. Aldershot: Ashgate.

Kaldjian, P. 2008. Presentation at Transitions in Modern Muslim Societies, Crossing Borders Convocation. lowa City, IA: University of lowa.

Kousis, M. 2004. Economic opportunities and threats in contentious environmental politics: a view from the European South. Theory and Society 3 (3/4): 393--415.

Kubicek, P. 2005. The European Union and grassroots democracy in Turkey. Turkish Studies 6 (3): 361-377. 
Kuus, M. 2007. Something old, something new: Eastness in European Union enlargement. Journal of International Relations and Development 10:150--167.

Lafferty, W. M., and J. Meadowcroft, eds. 1996. Democracy and the environment: Problems and prospects. Cheltenham, UK: Edward Elgar.

Lawhon, M., H. Ernstson, Silver and S. Fazel-Ellahi. 2012. Provincializing Urban Political Ecology: Expanding UPE through African Urbanism. Presented at South African Geographers Conference, Cape Town, South Africa, June 2012.

Latta, P. A. 2007. Citizenship and the politics of nature: the case of Chile's Alto Bio Bio. Citizenship Studies 11(3): 229-246.

Lohmann, L. 1993. Green orientalism. The Ecologist 23(6): 202--204.

Mawdesley, E. 2004. India's middle class and the environment. Development and Change 35 (1): 79-103.

Neumann, R. 1998. Imposing wilderness: Struggles over livelihood and nature preservation in Africa. Berkeley, CA: University of California Press.

Nightingale, A. J. 2011. Beyond design principles: subjectivity, emotion and the (ir)rational commons. Society and Natural Resources 2 (24): 119--132.

Nixon, R. 2005. Environmentalism and Postcolonialism. In Postcolonial Studies and Beyond, eds. Loomba, A., S. Kaul, M. Bunzi, A. Burton, and J. Esty, 233-251. Durham, NC: Duke University Press.

2011. Slow violence and environmentalism of the poor. Cambridge, MA: Harvard University Press. 
Ozden, M. 2008. Environmental awareness and attitudes of student teachers: an empirical research. International Research in Geographical and Environmental Education 17(1): 40--55.

Paley, J. 2002. Toward an anthropology of democracy. Annual Review of Anthropology 31:469--496.

Pamuk, O. 2006a. My father's suitcase, Nobel Lecture. 7 December 2006. http://nobelprize.org/nobel_prizes/literature/laureates/2006/pamuk-lecture_en.html (last accessed 25 July 2011).

Vintage.

2006b. Istanbul: memories and the city. Translated by M. Feely. New York:

Pile, S. 2010. Emotions and affect in recent human geography. Transactions of the Institute for British Geographers 35 (1): 5--20.

Pusch, B. 2005. The greening of islamic politics: a godsend for the environment. In Environmentalism in Turkey: Between democracy and development?, eds. Adaman, F., and M. Arsel, 131-148. Aldershot: Ashgate.

Ramm, C. 2009. Sick many beyond Europe: orientalization of Turkey and Turkish migrants in European accession discourses in Germany. In Racism Postcolonialism Europe, eds. Huggan, G., and I. Law, 102-115. Liverpool, UK: Liverpool University Press

Razack, S. 2002. Race, space, and the law: Unmapping a white settler society. Toronto, ON: University of Toronto Press.

Robbins, P. 2006. Research is theft: Environmental inquiry in a postcolonial world. In 
Approaches to human geography, eds. Aitken, S., and G. Valentine, 311--324. London, UK: SAGE publishers.

Robbins, P. 2007. Lawn people: How grasses, weeds, and chemicals make us who we are. Philadelphia, PA: Temple University Press.

Rumelili, B. 2007. Constructing regional community and order in Europe and Southeast Asia. New York, NY: Palgrave Macmillan.

Rutherford, S. 2007. Green governmentality: Insights and opportunities in the study of nature's rule. Progress in Human Geography 31 (3): 197--307.

Said, E. 1978. Orientalism. New York, NY: Vintage.

Satterfield, T. 2008. Emotional Agency and Contentious Practice: Activist disputes in old-growth forests. Ethos 32 (2): $233-256$.

Sawyer, S., and A. Agrawal. 2000. Environmental orientalisms. Cultural Critique 45:71-108.

Secor, A. 2003. Belaboring gender: the spatial practice of work and the politics of 'making do' in Istanbul. Environment and Planning A 35: 2209 - 2227.

Sharp, J. 2008. Geography and gender: What belongs to feminist geography? Emotion, power and change. Progress in Human Geography 33 (1): 1--7.

Smith, B. 2008. Key of green: Passion and perception in Renaissance culture. Chicago, IL: University of Chicago Press. 
Sparke, M. 2007. Everywhere but always somewhere: Critical geographies of the global south. The Global South 1 (1): 117--126.

Spivak, G. 2008. Other Asias. Malden, MA: Blackwell.

Sultana, F. 2011 Suffering for water, suffering from water: Emotional geographies of resource access, control and conflict. Geoforum 42 (2): 163-172.

Tocci, N. 2005. Europeanization in Turkey: Trigger or anchor for reform? South European Society \& Politics 10 (1): 73-83.

Tsing, A. 2005. Friction: An ethnography of global connection. Princeton, NJ and Oxford, UK: Princeton University Press.

Tuncer, G., H. Ertepinar, C. Tekkaya, and S. Sungur. 2005. Environmental attitudes of young people in Turkey: Effects of school type and gender. Environmental Education Research 11 (2): 215--233.

Tuncer, G., C. Tekkaya, S. Sungur, J. Cakiroglu, H. Ertepinar, and M. Kaplowitz. 2009. Assessing pre-service teacher's environmental literacy in Turkey as a mean to develop teacher education programs. International Journal of Educational Development 29 (4): 426--436.

Visier, C. 2009. Turkey and the European Union: The sociology of engaged actors and their contribution to the candidacy issue. European Journal of Turkish Studies 9.

Wainwright, J. 2005. The geographies of political ecology: After Edward Said. Environment and Planning A 37 (6): 1033--1043.

Willems-Braun, B. 1997. Buried epistemologies: The politics of nature in (post)colonial British Columbia. Annals of the Association of American Geographers 87(1): 3--31. 
Wong, S., and L. Sharp. 2009. Making power explicit in sustainable water innovation: Re-linking subjectivity, institutions and structure through environmental citizenship. Environmental Politics 18 (1): 37--57.

Woodward, K., and J. Lea. 2010. Geographies of affect. In The handbook of social geography, eds. Smith, S., R. Pain, S.A. Marston, and J.P. Jones III, 154--175. London, UK: Sage.

Wright, M. 2010. Geography and gender: Feminism and a feeling of justice. Progress in Human Geography 34 (6): 818--827.

Zurcher, E.-J. 2005a. How Europeans adopted Anatolia and created Turkey. European Review 13 (3): 379--394.

2005b. Ottoman sources of Kemalist thought. In Late Ottoman society: The intellectual legacy, ed. Ozdalga, E. 14--27. London, UK: Routledge. 